\title{
Flavobacterium weaverense sp. nov. and Flavobacterium segetis sp. nov., novel psychrophiles isolated from the Antarctic
}

\section{Correspondence Jongsik Chun jchun@snu.ac.kr}

\author{
Hana Yi and Jongsik Chun \\ School of Biological Sciences and Institute of Microbiology, Seoul National University, \\ 56-1 Shillim-dong, Kwanak-gu, Seoul 151-742, Republic of Korea
}

\begin{abstract}
Two psychrophilic flavobacteria, designated $\mathrm{AT} 1042^{\top}$ and $\mathrm{AT} 1048^{\top}$, were isolated from terrestrial samples from the Antarctic. Results of 16S rRNA gene sequence analyses indicated a close relationship of these isolates to Flavobacterium flevense $\left(96.9 \%\right.$ similarity for strain AT1042 ${ }^{\top}$ )

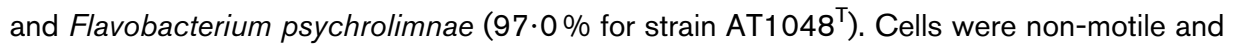
non-gliding. Flexirubin-type pigments were absent. Both isolates were psychrophilic, with an optimum and maximum growth temperature of about 15 and $20^{\circ} \mathrm{C}$, respectively. The major isoprenoid quinone, predominant cellular fatty acids and DNA G + C contents (35-37 mol\%) were consistent with the placement of the Antarctic isolates in the genus Flavobacterium. Phylogeny based on 16S rRNA gene sequences and several phenotypic characteristics could be used to differentiate these isolates from recognized Flavobacterium species. Despite high 16S rRNA gene

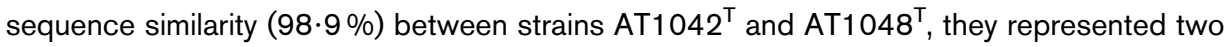
distinct species as demonstrated by low genomic relatedness (34\%) and a number of differential phenotypic characters. The polyphasic data presented in this study indicated that the new isolates should be classified within two novel species in the genus Flavobacterium. The names Flavobacterium weaverense sp. nov. (type strain AT1042 ${ }^{\top}=\mathrm{IMSNU} 14048^{\top}=\mathrm{KCTC}^{\mathrm{N}}$ $12223^{\top}=\mathrm{JCM} 12384^{\top}$ ) and Flavobacterium segetis sp. nov. (type strain AT1048 ${ }^{\top}=$ IMSNU $14050^{\top}=$ KCTC $12224^{\top}=\mathrm{JCM} 12385^{\top}$ ) are proposed for these Antarctic isolates.
\end{abstract}

Two psychrophilic bacterial strains, designated AT1042 ${ }^{\mathrm{T}}$ and $\mathrm{AT} 1048^{\mathrm{T}}$, were isolated from terrestrial samples from the Antarctic and subjected to a taxonomic study according to the minimal standards for describing novel taxa of the family Flavobacteriaceae (Bernardet et al., 2002). On the basis of the polyphasic evidence presented, the Antarctic strains are considered to represent two distinct novel species in the genus Flavobacterium.

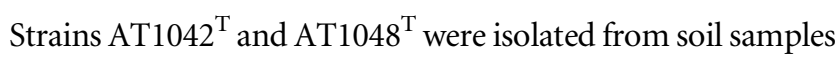
collected on the Weaver Peninsula $\left(62^{\circ} 14^{\prime} 07 \cdot 8^{\prime \prime} \mathrm{S} 58^{\circ} 46^{\prime}\right.$ $\left.33 \cdot 3^{\prime \prime} \mathrm{W}\right)$ and in a penguin habitat near the King Sejong Station $\left(62^{\circ} 12^{\prime} 17 \cdot 6^{\prime \prime} \mathrm{S} 58^{\circ} 47^{\prime} 40 \cdot 2^{\prime \prime} \mathrm{W}\right)$, respectively, on King George Island, Antarctica. Isolation was carried out using marine agar 2216 (MA; Difco) at $10^{\circ} \mathrm{C}$ following enrichment for 2 days in marine broth 2216 at $4{ }^{\circ} \mathrm{C}$. The isolates were cultured routinely on R2A (Difco) at $15^{\circ} \mathrm{C}$ and maintained as a glycerol suspension $(20 \%, \mathrm{w} / \mathrm{v}$, in distilled water) at $-80^{\circ} \mathrm{C}$.

The GenBank/EMBL/DDBJ accession numbers for the 16S rRNA gene sequences of strains AT1042 ${ }^{\top}$ and AT $1048^{\top}$ are AY581114 and AY581115, respectively.
The 16S rRNA gene was enzymically amplified from a single colony. Primers, PCR conditions and sequencing methods were as described by Chun \& Goodfellow (1995). The sequences of strains AT $1042^{\mathrm{T}}$ and $\mathrm{AT} 1048^{\mathrm{T}}$ were aligned manually with representative sequences of the family Flavobacteriaceae obtained from GenBank. Phylogenetic trees were inferred using the Fitch-Margoliash (Fitch \& Margoliash, 1967), maximum-likelihood (Felsenstein, 1993), maximumparsimony (Fitch, 1971) and neighbour-joining (Saitou \& Nei, 1987) methods. Evolutionary distance matrices for the neighbour-joining and Fitch-Margoliash methods were generated according to the model of Jukes \& Cantor (1969). Resultant tree topologies were evaluated by bootstrap analyses (Felsenstein, 1985) based on 1000 resamplings. Alignment and phylogenetic analyses were carried out using the jPHYDIT program (Jeon et al., 2005) and PAUP 4.0 (Swofford, 1998) as described by Chun et al. (2000) and Kim et al. (2005). Almost complete 16S rRNA gene sequences of strains $\mathrm{AT}_{1042^{\mathrm{T}}}(1402 \mathrm{bp})$ and AT1048 ${ }^{\mathrm{T}}(1395 \mathrm{bp})$ were obtained. Preliminary sequence comparison with $16 \mathrm{~S}$ rRNA gene sequences held in GenBank indicated that the new isolates were related closely to the genus Flavobacterium. The newly determined sequences were then aligned manually against representatives of Flavobacterium species using bacterial 16S 
rRNA gene secondary structure. The regions available for all sequences (positions 48-1468; Escherichia coli numbering system), excluding positions likely to show ambiguous alignment (positions 76-94), were used to generate phylogenetic trees. 16S rRNA gene sequence similarity between strains $\mathrm{AT} 1042^{\mathrm{T}}$ and $\mathrm{AT} 1048^{\mathrm{T}}$ was $98.9 \%$, and the two Antarctic isolates were consistently recovered as a monophyletic clade ( $100 \%$ bootstrap support) within the genus Flavobacterium in all tree-making methods used in this study. Strain AT1042 ${ }^{\mathrm{T}}$ showed highest 16S rRNA gene sequence similarity to Flavobacterium flevense ATCC $27944^{\mathrm{T}}$ (96.9\%), followed by Flavobacterium psychrolimnae LMG $22018^{\mathrm{T}}(96 \cdot 7 \%)$, Flavobacterium limicola ST-82 ${ }^{\mathrm{T}}(96 \cdot 6 \%)$ and Flavobacterium saccharophilum NCIMB $2072^{\mathrm{T}}(96 \cdot 5 \%)$. Strain $\mathrm{AT}_{1048^{\mathrm{T}}}$ showed highest $16 \mathrm{~S}$ rRNA gene sequence similarity with $F$. psychrolimnae LMG $22018^{\mathrm{T}}(97 \cdot 0 \%)$, followed by F. flevense ATCC $27944^{\mathrm{T}}$ (96.9\%), F. saccharophilum NCIMB $2072^{\mathrm{T}}(96 \cdot 7 \%)$ and F. limicola ST- $82^{\mathrm{T}}$ $(96.6 \%)$. In the phylogenetic trees generated in this study, strains $\mathrm{AT} 1042^{\mathrm{T}}$ and $\mathrm{AT} 1048^{\mathrm{T}}$ represented a distinct phyletic line corresponding to novel species in the genus Flavobacterium (Fig. 1).

Genomic relatedness between strains AT1042 ${ }^{\mathrm{T}}$ and $\mathrm{AT} 1048^{\mathrm{T}}$ was further examined using slot-blot DNA-DNA hybridization (Chun et al., 1998) as these isolates shared high 16S rRNA gene similarity $(98.9 \%)$, corresponding to $16 \mathrm{nt}$ differences. The two isolates shared a low DNA-DNA relatedness value of $34 \%$, which is well below the threshold (70\%) recommended for determining bacterial species (Wayne et al., 1987). It is clear from DNA-DNA hybridization experiments that strains AT $1042^{\mathrm{T}}$ and AT $1048^{\mathrm{T}}$ belong to separate genomic species.
Chemotaxonomic characteristics were determined from cultures grown at $15^{\circ} \mathrm{C}$ on R2A. Menaquinone was isolated from 7-day-old cells according to the method of Minnikin et al. (1984) and analysed by HPLC (Waters) as described by Collins (1985). DNA G +C content was determined by HPLC analysis of deoxyribonucleosides as described by Mesbah et al. (1989), by using a reversed-phase column (Supelco). Fatty acid methyl ester analysis was performed by GLC according to the Microbial Identification (MIDI) System using 5-day-old cells. The chemotaxonomic properties of the strains were consistent with those of the genus Flavobacterium and are given in the species descriptions below. The major fatty acids of the new isolates (Table 1) were similar to those of phylogenetically related species, although in slightly different proportions (Bernardet et al., 1996; Tamaki et al., 2003; Van Trappen et al., 2005).

Growth on several bacteriological media was tested using Anacker and Ordal agar [AOA; $10 \mathrm{~g}$ Bacto agar (Difco), $0.5 \mathrm{~g}$ Bacto tryptone (Difco), $0.5 \mathrm{~g}$ yeast extract (Difco), $0.2 \mathrm{~g}$ sodium acetate, $0 \cdot 2 \mathrm{~g}$ beef extract (Difco), per litre of distilled water], cetrimide agar (Difco), MacConkey agar (Difco), MA, nutrient agar (NA; Difco), R2A, trypticase soy agar (TSA; Difco) and sea-salt-free Zobell's agar [15 g Bacto agar, $5 \mathrm{~g}$ Bacto peptone (Difco), $1 \mathrm{~g}$ yeast extract, $0 \cdot 1 \mathrm{~g}$ ferric citrate, per litre of distilled water]. Maximum growth was observed on R2A. Abundant growth was also seen on AOA, MA, NA, TSA and sea-salt-free Zobell's agar. No growth was observed on cetrimide or MacConkey agar. Temperature ranges for growth were determined in a temperaturegradient incubator (TVS126MA; Advantec) using R2A broth in the range $5-25^{\circ} \mathrm{C}$. To determine cardinal temperatures, the resultant data were fitted to the Ratkowsky

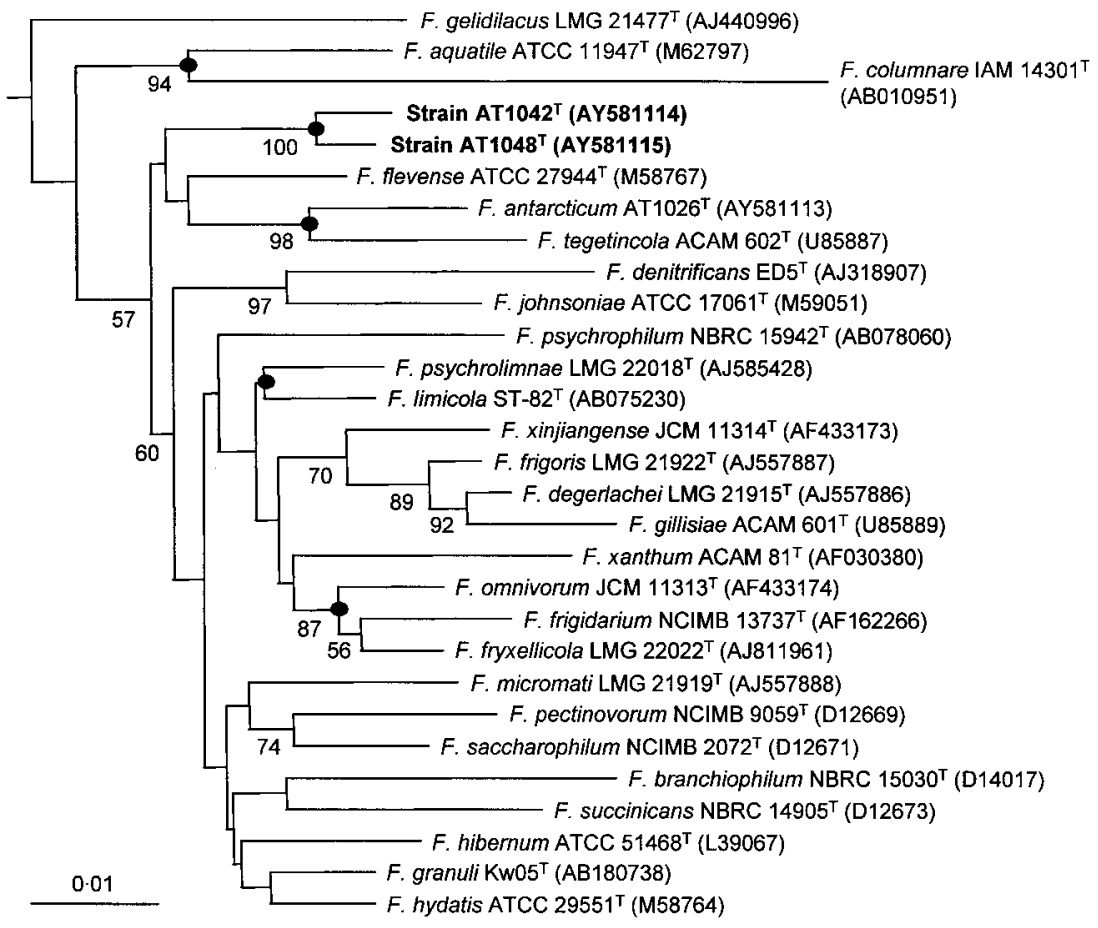

Fig. 1. Phylogenetic position of strains $\mathrm{AT}^{1042^{\top}}$ and $\mathrm{AT}^{\mathrm{T}} 1048^{\mathrm{T}}$ within the genus Flavobacterium, based on 16S rRNA gene sequences. The tree was created using the neighbour-joining method; numbers at nodes are percentage bootstrap support ( $>50 \%)$ from 1000 resampled datasets. Solid circles indicate that the corresponding nodes (groupings) were also recovered in Fitch-Margoliash, maximum-likelihood and maximum-parsimony trees. Cellulophaga lytica ATCC $23178^{\top}$ (M62796) was used as an outgroup (not shown). Bar, 0.01 substitutions per nucleotide position. 
Table 1. Cellular fatty acid composition (\% of total) of Flavobacterium weaverense sp. nov. $\mathrm{AT}^{\mathrm{T}} 1042^{\top}$ and Flavobacterium segetis sp. nov. AT1048

Fatty acids that amounted to $<1 \%$ of the total fatty acids in both strains were not included.

\begin{tabular}{|c|c|c|}
\hline Fatty acid & $\operatorname{AT} 1042^{\mathrm{T}}$ & AT1048 ${ }^{\mathrm{T}}$ \\
\hline iso- $\mathrm{C}_{14: 0}$ & $5 \cdot 1$ & $3 \cdot 6$ \\
\hline iso- $\mathrm{C}_{15: 1} \mathrm{G}^{*}$ & $3 \cdot 2$ & $4 \cdot 2$ \\
\hline anteiso- $C_{15: 1} A^{*}$ & $1 \cdot 1$ & $2 \cdot 0$ \\
\hline iso- $\mathrm{C}_{15: 0}$ & $3 \cdot 2$ & $4 \cdot 9$ \\
\hline anteiso- $\mathrm{C}_{15: 0}$ & $3 \cdot 7$ & $8 \cdot 5$ \\
\hline $\mathrm{C}_{15: 1} \omega 6 c$ & $14 \cdot 4$ & $8 \cdot 9$ \\
\hline $\mathrm{C}_{15: 0}$ & $8 \cdot 1$ & $5 \cdot 1$ \\
\hline iso- $\mathrm{C}_{14: 0} 3-\mathrm{OH}$ & $1 \cdot 1$ & $0 \cdot 9$ \\
\hline iso- $\mathrm{C}_{16: 1} \mathrm{H}^{\star}$ & $11 \cdot 8$ & $7 \cdot 0$ \\
\hline iso- $\mathrm{C}_{16: 0}$ & $8 \cdot 6$ & $4 \cdot 8$ \\
\hline Summed feature $3 \dagger$ & $5 \cdot 7$ & $13 \cdot 5$ \\
\hline $\mathrm{C}_{16: 0}$ & $0 \cdot 8$ & $1 \cdot 3$ \\
\hline iso- $\mathrm{C}_{15: 0} 3-\mathrm{OH}$ & $2 \cdot 8$ & $4 \cdot 5$ \\
\hline iso- $\mathrm{C}_{17: 1} \omega 9 c$ & $1 \cdot 0$ & $1 \cdot 7$ \\
\hline $\mathrm{C}_{15: 0} 3-\mathrm{OH}$ & $1 \cdot 5$ & $1 \cdot 5$ \\
\hline $\mathrm{C}_{17: 1} \omega 6 c$ & $8 \cdot 0$ & $7 \cdot 1$ \\
\hline iso- $\mathrm{C}_{16: 0} 3-\mathrm{OH}$ & $14 \cdot 8$ & $11 \cdot 0$ \\
\hline $\mathrm{C}_{16: 0} 3-\mathrm{OH}$ & $0 \cdot 5$ & $1 \cdot 0$ \\
\hline iso- $\mathrm{C}_{17: 0} 3-\mathrm{OH}$ & $2 \cdot 1$ & $3 \cdot 5$ \\
\hline
\end{tabular}

*The double-bond position indicated by capital letters is unknown. $\dagger$ Summed features are groups of two or three fatty acids that cannot be separated by GLC with the MIDI system. Summed feature 3 contains $\mathrm{C}_{16: 1} \omega 7 c$ and/or iso- $\mathrm{C}_{15: 0} 2-\mathrm{OH}$.

temperature growth model (Ratkowsky et al., 1983) by nonlinear regressions using the $\mathrm{R}$ 1.8.1 statistical package ( $R$ Foundation for Statistical Computing, 2003). Square-root growth rate - temperature plots showed that the notional minimum, optimum and maximum growth temperatures were $-29 \cdot 7,15 \cdot 3$ and $19 \cdot 9{ }^{\circ} \mathrm{C}$, respectively, for strain $\mathrm{AT} 1042^{\mathrm{T}}$ and $-29 \cdot 7,14 \cdot 3$ and $18 \cdot 9^{\circ} \mathrm{C}$, respectively, for strain $\mathrm{AT}^{\mathrm{T}} 1048^{\mathrm{T}}$ (Fig. 2). When tested on R2A (between 5 and $25^{\circ} \mathrm{C}$ at $5^{\circ} \mathrm{C}$ intervals), both strains failed to grow at $25^{\circ} \mathrm{C}$. Following the definition of Isaksen \& Jørgensen (1996), the Antarctic isolates can be defined as psychrophiles. The minimum doubling times of strains AT $1042^{\mathrm{T}}$ and $\mathrm{AT} 1048^{\mathrm{T}}$ were about $2 \cdot 9$ and $6 \cdot 8 \mathrm{~h}$, respectively. Growth at different $\mathrm{pH}$ (between $\mathrm{pH} 4$ and 12 at intervals of $1 \mathrm{pH}$ unit) and $\mathrm{NaCl}$ concentrations [between 0 and $7 \%(\mathrm{w} / \mathrm{v})$ at intervals of $1 \%$ ] was determined using sea-salt-free ZoBell's medium. $\mathrm{KOH}$ and $\mathrm{HCl}$ (both at $6 \mathrm{M}$ ) were used to adjust the final $\mathrm{pH}$. Growth was also assessed under anaerobic (with 4-10\% $\mathrm{CO}_{2}$ ) and microaerobic (with 5-15\% $\mathrm{O}_{2}$ and 5-12\% $\mathrm{CO}_{2}$ ) conditions, using GasPak Plus and CampyPak Plus systems (BBL) at $15^{\circ} \mathrm{C}$ for up to 1 month. Detailed results of these growth experiments are given in the species descriptions.

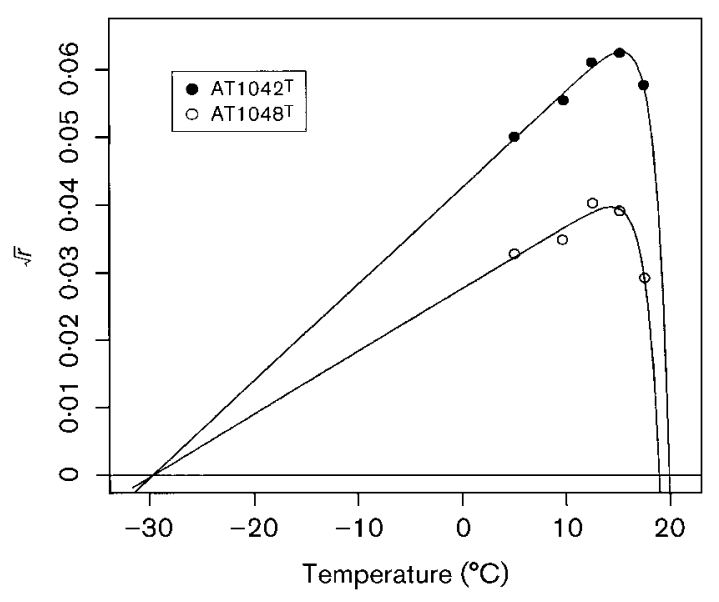

Fig. 2. Fitted Ratkowsky model of growth versus temperature data for strains AT1042 ${ }^{\top}$ and AT1048 ${ }^{\top} . \sqrt{ } r$ is the square-root of growth rate.

Morphological and physiological tests were performed using $\mathrm{R} 2 \mathrm{~A}$ as the basal medium at $15^{\circ} \mathrm{C}$. Cellular morphology and motility were examined by scanning electron microscopy and phase-contrast microscopy using 3-, 5- and 10-day-old cells. Gliding motility was observed by direct microscopic examination of the edge of colonies in exponential phase on AOA, R2A and CY agar [ 3 g casitone (Difco), 1 g yeast extract, $1 \mathrm{~g} \mathrm{CaCl}_{2} \cdot 2 \mathrm{H}_{2} \mathrm{O}, 40 \mathrm{~g}$ sea salts (Sigma), $15 \mathrm{~g}$ Bacto agar, per litre of distilled water] plates, and motility was observed by the hanging drop technique with cells in exponential phase in R2A and CY broth. The presence of flexirubin-type pigments was determined by flooding the agar plate or biomass with $20 \%(\mathrm{w} / \mathrm{v}) \mathrm{KOH}$ and was then confirmed by measuring the absorbance spectrum of an ethanol and alkaline-ethanol extract of lysed cells (Weeks, 1981). Congo red adsorption was tested by directly flooding colonies on agar plates with $0.01 \%$ aqueous Congo red solution.

Standard physiological and biochemical tests were performed at $15{ }^{\circ} \mathrm{C}$ as described by Smibert \& Krieg (1994). Hydrolysis of alginate $(0.5 \%$, w/v), casein [50\% skimmed milk (Difco), v/v], carboxymethylcellulose (CM-cellulose) [0.5\% CM-cellulose (Sigma), w/v], chitin $(0 \cdot 5 \%$ colloidal chitin, w/v), egg yolk $(5 \%$, w/v), elastin $(0.5 \%, w / v)$, starch $(0 \cdot 2 \%, \mathrm{w} / \mathrm{v})$, Tween $80(1 \%, \mathrm{v} / \mathrm{v})$ and L-tyrosine $(0.5 \%$, $\mathrm{w} / \mathrm{v})$ was tested using R2A as the basal medium. PEK7 agar (Reichenbach, 1992) and DNase test agar (Difco) were used for pectinase and DNase assays, respectively. Production of $\mathrm{H}_{2} \mathrm{~S}$ was investigated using triple-sugar iron agar (Difco). Phenylalanine deaminase activity was determined on phenylalanine agar (Smibert \& Krieg, 1994; 3 g yeast extract, $1 \mathrm{~g}$ L-phenylalanine, $1 \mathrm{~g} \mathrm{Na}_{2} \mathrm{HPO}_{4}, 5 \mathrm{~g} \mathrm{NaCl}, 12 \mathrm{~g}$ Bacto agar, per litre of distilled water). Alkaline reaction on Christensen's citrate was tested on Christensen citrate agar (Christensen, 1949). Arginine dihydrolase and urease activities were determined using Thornley's semi-solid medium 
(Thornley, 1960) and Christensen urea agar (Christensen, 1946), respectively. Acid production from carbohydrates was examined for up to 1 month using modified $\mathrm{O} / \mathrm{F}$ agar plates (Leifson, 1963; $1.0 \mathrm{~g}$ casitone, $0.1 \mathrm{~g}$ yeast extract, $0.5 \mathrm{~g}$ ammonium sulfate, $0.5 \mathrm{~g}$ Tris base, $0.01 \mathrm{~g}$ phenol red, $15 \mathrm{~g}$ Bacto agar, per litre of distilled water, adjusted to $\mathrm{pH} 7 \cdot 0$ ). Nitrate and nitrite reduction, production of indole, aesculinase, gelatinase and $\beta$-galactosidase and assimilation of sole carbon sources (glucose, arabinose, mannose, mannitol, $\mathrm{N}$-acetylglucosamine, maltose, gluconate, caprate, adipate, malate, citrate and phenylacetate) were tested using the API 20NE kit (bioMérieux) and other enzyme activities were determined using the API ZYM kit (bioMérieux). The results of morphological, biochemical and physiological tests are given in Table 2 and in the species descriptions.

On the basis of $16 \mathrm{~S}$ rRNA gene sequence analyses, the two Antarctic isolates are considered to represent an independent novel phyletic line in a clade encompassing different members of the genus Flavobacterium. These strains are further differentiated by a low level of genomic relatedness (34\%) and a number of phenotypic characters, namely colonial pigmentation, production of aesculinase, DNase, $\beta$-galactosidase, urease, arginine dihydrolase and $\alpha$-fucosidase

Table 2. Characteristics that differentiate strains $A T 1042^{\top}$ and $\mathrm{AT}_{1048^{\top}}$ from related Flavobacterium species

Taxa: 1, F. weaverense sp. nov. AT1042 $2^{\mathrm{T}} ; 2$, F. segetis sp. nov. $\mathrm{AT} 1048^{\mathrm{T}}$; 3, F. flevense; 4, F. psychrolimnae; 5, F. limicola; 6, F. saccharophilum. +, Positive; -, negative; W, weakly positive; $\mathrm{V}$, variable; ND, not determined; C, clear zone formed on egg-yolk agar. Data are taken from this study and from Bernardet et al. (1996), Tamaki et al. (2003) and Van Trappen et al. (2005).

\begin{tabular}{|c|c|c|c|c|c|c|}
\hline Characteristic & 1 & 2 & 3 & 4 & 5 & 6 \\
\hline Growth at $25^{\circ} \mathrm{C}$ on agar & - & - & + & + & + & + \\
\hline Congo red absorption & - & - & - & - & + & - \\
\hline Growth on seawater media & + & + & + & - & - & - \\
\hline Gliding motility & - & - & + & - & - & + \\
\hline Flexirubin-type pigments & - & - & - & - & - & + \\
\hline Acid from carbohydrates & + & + & + & - & - & ND \\
\hline \multicolumn{7}{|l|}{ Degradation of: } \\
\hline Gelatin & - & - & - & - & + & + \\
\hline Casein & + & + & - & + & + & + \\
\hline CM-cellulose & - & - & - & - & - & + \\
\hline Agar & - & - & + & - & + & + \\
\hline Pectin & - & - & + & - & - & + \\
\hline Aesculin & - & + & + & + & + & + \\
\hline DNA & - & + & - & - & - & - \\
\hline Tyrosine & $\mathrm{W}$ & $\mathrm{W}$ & - & - & + & + \\
\hline Brown pigment on tyrosine agar & $\mathrm{W}$ & $\mathrm{W}$ & - & - & + & - \\
\hline Precipitate formed on egg-yolk agar & $\mathrm{C}$ & - & - & - & - & - \\
\hline$\beta$-Galactosidase activity & - & + & + & + & - & + \\
\hline $\mathrm{H}_{2} \mathrm{~S}$ production & - & - & - & - & - & + \\
\hline Nitrate reduction & - & - & $\mathrm{V}$ & - & - & + \\
\hline
\end{tabular}

and acid production from lactose, D-trehalose, sucrose and D-cellobiose. Therefore, we conclude that strains $\mathrm{AT} 1042^{\mathrm{T}}$ and $\mathrm{AT} 1048^{\mathrm{T}}$ should be assigned to the genus Flavobacterium as the type strains of two separate novel species.

\section{Description of Flavobacterium weaverense sp. nov.}

Flavobacterium weaverense (wea.ver.en'se. N.L. neut. adj. weaverense pertaining to the Weaver Peninsula, the geographical origin of the type strain).

Gram-negative, oxidase- and catalase-positive and psychrophilic. Cells are non-motile long rods during the exponential phase (approx. 1.6-12.5 $\times 0.3-0.5 \mu \mathrm{m}$ ) and become short rods during the stationary phase (approx. $0 \cdot 7-1 \cdot 5 \times 0 \cdot 3$ $0 \cdot 4 \mu \mathrm{m})$. Colonies are convex, translucent, glistening, viscid, yellow, circular with entire margins and become mucoid after prolonged incubation on R2A or AOA. Does not glide or adhere to agar plates. Flexirubin-type pigments are absent. Congo red is not adsorbed. Spores are not formed. Growth occurs on R2A, AOA, MA, NA and TSA, but not on cetrimide or MacConkey agar. Grows well under aerobic conditions, weakly under microaerobic conditions (with 5-15\% $\mathrm{O}_{2}$ and $5-12 \% \mathrm{CO}_{2}$, created by use of the CampyPack Plus system) and poorly under anaerobic conditions (with $4-10 \% \mathrm{CO}_{2}$, created by use of the GasPack Plus system). Growth occurs at $\mathrm{pH}$ 6-12 (optimum $\mathrm{pH} 6-7$ ) and with $0-3 \% \mathrm{NaCl}$ (optimum $1 \%$ ). Grows at $5 \cdot 0-19 \cdot 9^{\circ} \mathrm{C}$ with notional minimum, optimum and maximum growth temperatures of $-29 \cdot 7,15 \cdot 3$ and $19 \cdot 9^{\circ} \mathrm{C}$, respectively. Minimum doubling time is $2.9 \mathrm{~h}$. Decomposes starch and Tween 80 , but not alginate, chitin or elastin. Positive reaction for urease. Negative reactions for L-phenylalanine deaminase, indole production and alkalinization on Christensen's citrate agar. Test for arginine dihydrolase is positive on Thornley's semisolid medium, but negative with the API 20NE kit. Produces acid from $\mathrm{D}$-glucose and maltose, but not from $\mathrm{D}$-cellobiose, D-fructose, D-mannitol, D-raffinose, D-salicin, D-trehalose, D-xylose, lactose, L-arabinose, L-rhamnose or sucrose. In API ZYM kits, alkaline phosphatase, esterase lipase (C8), leucine arylamidase, valine arylamidase, acid phosphatase, naphthol-AS-BI-phosphohydrolase, $\alpha$-glucosidase, $N$-acetyl$\beta$-glucosaminidase and $\alpha$-fucosidase activities are present; weak cystine arylamidase and trypsin activities are present; and esterase (C4), lipase (C14), $\alpha$-chymotrypsin, $\alpha$-galactosidase, $\beta$-galactosidase, $\beta$-glucuronidase, $\beta$-glucosidase and $\alpha$-mannosidase activities are absent. Assimilates glucose, mannose, $\mathrm{N}$-acetylglucosamine and maltose as sole carbon sources in API 20NE kits, but not arabinose, mannitol, gluconate, caprate, adipate, malate, citrate or phenylacetate. Other physiological and biochemical characteristics are given in Table 2. Maximum absorption peak of pigment is at $451 \mathrm{~nm}$ and the next shoulder is at $479 \mathrm{~nm}$. Major isoprenoid quinone is MK-6. Predominant cellular fatty acids are $\mathrm{C}_{15: 1} \omega 6 c$, iso- $\mathrm{C}_{16: 1} \mathrm{H}$ and iso- $\mathrm{C}_{16: 0} 3-\mathrm{OH}$; the full fatty acid profile is given in Table 1 . DNA G $+\mathrm{C}$ content of the type strain is $37 \mathrm{~mol} \%$. 
The type strain, AT1042 ${ }^{\mathrm{T}}\left(=\mathrm{IMSNU} 14048^{\mathrm{T}}=\mathrm{KCTC}\right.$ $12223^{\mathrm{T}}=$ JCM $12384^{\mathrm{T}}$ ), was isolated from a soil sample from the Weaver Peninsula, King George Island, Antarctica.

\section{Description of Flavobacterium segetis sp. nov.}

Flavobacterium segetis (se.ge'tis. L. gen. n. segetis of the soil).

Gram-negative, oxidase- and catalase-positive and psychrophilic. Cells are rod-shaped with rounded ends, approximately $1 \cdot 1-2 \cdot 3 \times 0 \cdot 2-0 \cdot 3 \mu \mathrm{m}$ and non-motile. Colonies are convex, translucent, glistening, butyrous, orange, circular with entire margins and become mucoid after prolonged incubation on R2A or AOA. Does not glide or adhere to agar plates. Flexirubin-type pigments are absent. Congo red is not adsorbed. Spores are not formed. Growth occurs on R2A, AOA, MA, NA and TSA, but not on cetrimide or MacConkey agar. Grows well under aerobic conditions, weakly under microaerobic conditions (with $5-15 \% \mathrm{O}_{2}$ and 5-12\% $\mathrm{CO}_{2}$ created by use of the CampyPack Plus system) and poorly under anaerobic conditions (with $4-10 \% \mathrm{CO}_{2}$ created by use of the GasPack Plus system). Growth occurs at $\mathrm{pH}$ 6-11 (optimum $\mathrm{pH} 7$ ) and with $0-3 \% \mathrm{NaCl}$ (optimum $0 \%$ ). Grows at $5 \cdot 0-21 \cdot 8{ }^{\circ} \mathrm{C}$ with notional minimum, optimum and maximum growth temperatures of $-29 \cdot 7,14 \cdot 3$ and $18.9^{\circ} \mathrm{C}$, respectively. Minimum doubling time is $6.8 \mathrm{~h}$. Decomposes starch and Tween 80 , but not alginate, chitin or elastin. Negative reactions for arginine dihydrolase, urease, L-phenylalanine deaminase, indole production and alkalinization on Christensen's citrate agar. Produces acid from D-cellobiose, D-glucose, D-trehalose, maltose and sucrose, but not from D-fructose, D-mannitol, D-raffinose, D-salicin, D-xylose, L-arabinose or L-rhamnose. Produces acid from lactose after prolonged incubation (4 weeks). In API ZYM kits, alkaline phosphatase, leucine arylamidase, valine arylamidase, acid phosphatase, naphthol-AS-BI-phosphohydrolase, $\alpha$-glucosidase and $N$-acetyl- $\beta$-glucosaminidase activities are present; weak esterase lipase (C8), cystine arylamidase, trypsin and $\beta$-glucosidase activities are present; and esterase (C4), lipase (C14), $\alpha$-chymotrypsin, $\alpha$-galactosidase, $\beta$-galactosidase, $\beta$-glucuronidase, $\alpha$-mannosidase and $\alpha$-fucosidase activities are absent. Assimilates glucose, mannose, $\mathrm{N}$-acetylglucosamine (weakly) and maltose as sole carbon sources in API 20NE kits, but not arabinose, mannitol, gluconate, caprate, adipate, malate, citrate or phenylacetate. Other physiological and biochemical characteristics are given in Table 2. Maximum absorption peak of pigment is at $472 \mathrm{~nm}$ and the next shoulder is at $452 \mathrm{~nm}$. Major isoprenoid quinone is MK-6. Predominant cellular fatty acids are iso- $\mathrm{C}_{16: 0} 3-\mathrm{OH}$ and summed feature 3 (containing $\mathrm{C}_{16: 1} \omega 7 c$ and/or iso- $\mathrm{C}_{15: 0} 2-\mathrm{OH}$ ); the full fatty acid profile is given in Table 1 . DNA G $+\mathrm{C}$ content of the type strain is $35 \mathrm{~mol} \%$.

The type strain, AT1048 ${ }^{\mathrm{T}}\left(=\mathrm{IMSNU} 14050^{\mathrm{T}}=\mathrm{KCTC}\right.$ $12224^{\mathrm{T}}=\mathrm{JCM} 12385^{\mathrm{T}}$ ), was isolated from a soil sample of a penguin habitat near the King Sejong Station on King George Island, Antarctica.

\section{Acknowledgements}

We are grateful to Dr J. P. Euzéby for help with nomenclature. This work was supported by the Korean Ministry of Science and Technology under the National Research Laboratory Program (M1050000011005J0000-11010), the KOPRI project (grant PE05004) and the BK21 Research Fellowship (the Ministry of Education and Human Resources Development), Republic of Korea.

\section{References}

Bernardet, J.-F., Segers, P., Vancanneyt, M., Berthe, F., Kersters, K. \& Vandamme, P. (1996). Cutting a Gordian knot: emended classification and description of the genus Flavobacterium, emended description of the family Flavobacteriaceae, and proposal of Flavobacterium hydatis nom. nov. (basonym, Cytophaga aquatilis Strohl and Tait 1978). Int J Syst Bacteriol 46, 128-148.

Bernardet, J. F., Nakagawa, Y. \& Holmes, B. (2002). Proposed minimal standards for describing new taxa of the family Flavobacteriaceae and emended description of the family. Int J Syst Evol Microbiol 52, 1049-1070.

Christensen, W. B. (1946). Urea decomposition as a means of differentiating Proteus and paracolon cultures from each other and from Salmonella and Shigella types. J Bacteriol 52, 461-466.

Christensen, W. B. (1949). Hydrogen sulfide production and citrate utilization in the differentiation of enteric pathogens and coliform bacteria. Research Bulletin no. 1. Greeley, CO: Weld County Health Department.

Chun, J. \& Goodfellow, M. (1995). A phylogenetic analysis of the genus Nocardia with $16 \mathrm{~S}$ rRNA gene sequences. Int $J$ Syst Bacteriol 45, 240-245.

Chun, J., Seong, C. N., Bae, K. S., Lee, K. J., Kang, S. O., Goodfellow, M. \& Hah, Y. C. (1998). Nocardia flavorosea sp. nov. Int $J$ Syst Bacteriol 48, 901-905.

Chun, J., Bae, K. S., Moon, E. Y., Jung, S. O., Lee, H. K. \& Kim, S. J. (2000). Nocardiopsis kunsanensis sp. nov., a moderately halophilic actinomycete isolated from a saltern. Int J Syst Evol Microbiol 50, 1909-1913.

Collins, M. D. (1985). Analysis of isoprenoid quinones. Methods Microbiol 18, 329-366.

Felsenstein, J. (1985). Confidence limits on phylogenies: an approach using the bootstrap. Evolution 39, 783-791.

Felsenstein, J. (1993). PHYLIP - Phylogeny Inference Package, version 3.5c. Distributed by the author. Department of Genome Sciences, University of Washington, Seattle, USA.

Fitch, W. M. (1971). Toward defining the course of evolution: minimum change for a specific tree topology. Syst Zool 20, 406-416.

Fitch, W. M. \& Margoliash, E. (1967). Construction of phylogenetic trees: a method based on mutation distances as estimated from cytochrome $c$ sequences is of general applicability. Science 155, 279-284.

Isaksen, M. F. \& Jørgensen, B. B. (1996). Adaptation of psychrophilic and psychrotrophic sulfate-reducing bacteria to permanently cold marine environments. Appl Environ Microbiol 62, 408-414.

Jeon, Y.-S., Chung, H., Park, S., Hur, I., Lee, J.-H. \& Chun, J. (2005). jPHYDIT: a JAVA-based integrated environment for molecular phylogeny of ribosomal RNA sequences. Bioinformatics 21, 3171-3173.

Jukes, T. H. \& Cantor, C. R. (1969). Evolution of protein molecules. In Mammalian Protein Metabolism, vol. 3, pp. 21-132. Edited by H. N. Munro. New York: Academic Press.

Kim, B. S., Oh, H. M., Kang, H. \& Chun, J. (2005). Archaeal diversity in tidal flat sediment as revealed by $16 \mathrm{~S}$ rDNA analysis. $J$ Microbiol 43, 144-151.

Leifson, E. (1963). Determination of carbohydrate metabolism of marine bacteria. J Bacteriol 85, 1183-1184. 
Mesbah, M., Premachandran, U. \& Whitman, W. B. (1989). Precise measurement of the $\mathrm{G}+\mathrm{C}$ content of deoxyribonucleic acid by highperformance liquid chromatography. Int J Syst Bacteriol 39, 159-167.

Minnikin, D. E., O’Donnell, A. G., Goodfellow, M., Alderson, G., Athayle, M., Schaal, A. \& Parlett, J. H. (1984). An integrated procedure for the extraction of isoprenoid quinones and polar lipids. J Microbiol Methods 2, 233-241.

Ratkowsky, D. A., Lowry, R. K., McMeekin, T. A., Stokes, A. N. \& Chandler, R. E. (1983). Model for bacterial culture growth rate throughout the entire biokinetic temperature range. J Bacteriol 154, 1222-1226.

Reichenbach, H. (1992). The order Cytophagales. In The Prokaryotes, 2nd edn, vol. 4, pp. 3631-3675. Edited by A. Balows, H. G. Trüper, M. Dworkin, W. Harder \& K. H. Schleifer. New York: Springer.

R Foundation for Statistical Computing (2003). R version 1.8.1. Vienna: Vienna University of Technology. http://www.r-project.org

Saitou, N. \& Nei, M. (1987). The neighbor-joining method: a new method for reconstructing phylogenetic trees. Mol Biol Evol 4, 406-425.

Smibert, R. M. \& Krieg, N. R. (1994). Phenotypic characterization. In Methods for General and Molecular Bacteriology, pp. 607-654. Washington, DC: American Society for Microbiology.
Swofford, D. L. (1998). PAUP - Phylogenetic Analysis Using Parsimony, version 4. Sunderland, MA: Sinauer Associates.

Tamaki, H., Hanada, S., Kamagata, Y., Nakamura, K., Nomura, N., Nakano, K. \& Matsumura, M. (2003). Flavobacterium limicola sp. nov., a psychrophilic, organic-polymer-degrading bacterium isolated from freshwater sediments. Int J Syst Evol Microbiol 53, 519-526.

Thornley, M. J. (1960). The differentiation of Pseudomonas from other gram-negative bacteria on the basis of arginine metabolism. J Appl Bacteriol 23, 37-52.

Van Trappen, S., Vandecandelaere, I., Mergaert, J. \& Swings, J. (2005). Flavobacterium fryxellicola sp. nov. and Flavobacterium psychrolimnae sp. nov., novel psychrophilic bacteria isolated from microbial mats in Antarctic lakes. Int J Syst Evol Microbiol 55, 769-772.

Wayne, L. G., Brenner, D. J., Colwell, R. R. \& 9 other authors (1987). Report of the ad hoc committee on reconciliation of approaches to bacterial systematics. Int J Syst Bacteriol 37, 463-464.

Weeks, O. B. (1981). Preliminary studies of the pigments of Flavobacterium breve NCTC 11099 and Flavobacterium odoratum NCTC 11036. In The Flavobacterium-Cytophaga Group, pp. 108-114. Edited by $\mathrm{O}$. B. Weeks. Weinheim: Gesellschaft für Biotechnologische Forschung. 